\title{
Lihavõtted Eestis 20. sajandil
}

\begin{abstract}
Mare Kõiva
Teesid: Artikkel vaatleb keskse kevad- ja ristiusu püha lihavõtete tähistamist sajandite vältel ja püha nihkumist privaatsfääri 20. sajandil. Viimase saja aasta jooksul on tähistamisviis oluliselt muutunud. Keskseteks sümboliteks jäid pühademunad, -kaardid, pajutibud jm põlised pühademärgid ja sotsiaalsete suhete kinnitajad. Vaadeldakse peamisi muutuste põhjustajaid: majandusmuutused, sekulariseerumine, urbaniseerumine ja Teise maailmasõja järgne kultuuripoliitika; kombestiku toetaja rolli kandumine haridus- ja kultuuriasutustele. Setu traditsioon võimaldas oma eripära tõttu lihavõtteid käsitleda religioosse ja rahvusliku identiteedi osana.
\end{abstract}

Märksõnad: Kagu-Eesti, lihavõtted, lihavõttemunad, rahvakalender, traditsioon

Kui väiksed olime, algas peale sööki põnev otsimismäng. Pühadejänes oli meil käinud ja mune kuhugi peitnud. Munad aga polnud tavalised, vaid šokolaadist (oli ka komme ja šokolaadijäneseid). See, kes midagi leidis, võis kohe ära sü̈̈a. Hästi tore oli. Nü̈d pole seda enam mänginud, sest oleme juba suured.

Käime ka vanaemale ja vanaisale häid pühi soovimas ja vahetame mune. Ka neil on pühade ajal laud kaetud ja piduroad laual. Sellepärast ongi meil juba kombeks, et pühade ajal lõunatame nende juures. Olgu need siis lihavõtted või mõni muu püha.

Pühad on väga ilusad ja mõnusad. Siis saab alati perega koos olla, vahel ka mõnda vana sõpra kohata, kes nü̈̈d mujal elab ja ainult vahel siiakanti külla käib (Kena 2006: http://www.miksike.ee/docs/referaadid/ minu_pere_traditsioonid_ranno.htm).

Selle veebiõpikeskkonda Miksike kirjutatud peretraditsioonide loo autor on teismeline poiss Ranno. Samahästi võinuks seesuguse meenutuse kirjutada ma ise ja arvatavasti paljud enne või pärast Teist maailmasõda sündinud eestlased.

http://haldjas.folklore.ee/tagused/nr32/lihavote.pdf 
Lihavõtted olid mu lapsepõlves oluline kodune püha, meeldejääv salapärase pühadejänese, saabuvate lihavõttekaartide, värviliste munade kinkimise ja vahetamise tõttu. Seda ka kooliajal, kui õpetajale ja pinginaabrile sai kooli mune viidud, alguses kombe tõttu, sest nii oli tavaks teha, kuid keskkoolis ehk ka epaterii tõttu. Ei ole selles päris kindel. Tahtsime 1970. aastate alguseski oma, eesti kombeid järgida, kuid milleks suunas kodune kasvatus ja peretraditsioon, mille aga ise taasleiutasime, seda on raske tagantjärele hinnata. Rahvakalendriuurimustes on siiani 20. sajandi jooksul aset leidnud muutustest vähe juttu olnud ning lihavõttejänesed, -kaardid, šokolaadimunad jm nähtused on liigitatud hilislaenuliste hulka. Esiplaanil on olnud agraarne 19. sajandi ja 20. sajandi alguse pärimus, mis rõhutab ühist ja jagatud samasust.

Martin Sökefeld (1999: 417) toob oma uurimuses esile, et viimaste aastate identiteediuurimustes on nihkutud identiteedi kui lapsepõlves omandatud kindlate isiksust loovate ja tema tegutsemises avalduvate isiksuseomaduste käsitlemise juurest nt sotsiaalantropoloogias tavalisema isiksuseni etnilise identiteedi kontekstis. Seejuures rõhutatakse sarnasust teiste samasse rühma kuulujatega ehk siis kindlaid karakteristikuid, nagu keel, kultuur jne, mida teadlikult teistega jagatakse ning mille abil moodustatakse rühma kuulujate sarnane identiteet. Ennekõike rühmaidentiteedile toetuvate variatsioonide, kuid ikkagi ühtsete kalendripärimuse peajoonte kirjeldamisele on olnud orienteeritud enamik seniseid käsitlusi, kuivõrd tähtpäevad on olemuslikult ühistegevusele orienteeritud. Kuigi antropoloogias on viimastel kümnenditel pööratud tähelepanu isiksusekesksele lähenemisele, on seda rituaalide ja kalendrinähtuste puhul keerukas teha.

Vaatlen lihavõtteid ühena kesksetest tähtpäevadest, mille puhul rahva kui selle tähistajate kompetents (McCauley \& Lawson 2002: 9) on püsinud pikki sajandeid, vaatamata mõnesugustele muutustele kombestikus. Lihavõtted olulise kevad-, keskse kirikupüha ja religioossete rituaalidega tähtpäevana on säilitanud oma stabiilsuse, tuginedes üldisele religioossete rituaalide järjepidevusele ja tasakaalustatusele. Jälgin 20. sajandini püsinud ja siis veel tuntud tavasid, mis tähendab, et olen püüdnud integreerida kalendritavandisse linnapärimust. Linnastumine jõudis 1938. aastaks 36\%ni ja sajandi teisel poolel elas linnades juba üle poole eestlastest. See tähendas varasema kombestiku mugandamist uuenevate oludega, tavandi mõne osa paratamatut kõrvalejäämist, kuid ka püsijoonte esiletõusmist.

Just sel perioodil on põhjust käsitleda lihavõtteid privaatsfääri aspektist, perekonnale ja ennekõike lastele orienteeritud pühana ning jälgida sinna nihkumise põhjusi. Lühemalt iseloomustatakse hääbunud kombestikku ja selle lokaalseid erijooni ühe rahvusriigi piires, kombestiku toetaja rolli ülekandu- 
mist koolidele, kultuurikeskustele jt institutsioonidele, poliitika ja rahvusluse ideede mõju kalendripärimusele ning pärimust lokaalse identiteedi osana.

Ajaliste raamide valimisel oli otsustav piisava hulga üleskirjutuste olemasolu, samuti detailsemad kirjeldused majandus- ja ajalooliste olude muutumisest. Kalendritavandit on kohalike kirjasaatjate abiga kogutud natuke rohkem kui saja aasta jooksul. Koos mitut liiki ennete, töökeeldude, elatusaladega seotud teadete, spetsiaalsete kommete, tähtpäevale omaste rituaalsete toitude, meelelahutuste jm moodustab see umbkaudu 180000 teate suuruse korpuse. 20. sajandi traditsiooni rohkus osutab lihavõtete püsimisele elavas pärimuses. Teisalt jätab see ennekõike retrospektiivne, võimalikult vanemat teavet jäädvustama orienteeritud teatekogum tagaplaanile vahetu empiirilise kogemuse ja konkreetsele kogumisajale iseloomulikud tähistamisviisid. Muidugi ei saa nii väita kõigi kirjasaatjate puhul - on ehedaid faktirohkeid, kuid ka emotsionaalselt paljupakkuvaid kirjapanekuid. Siiski erinevad viimaste kümnendite kirjapanekud varasematest, sest neis on rohkem vahetuid isiklikke kogemusi ja mälestusi, mistõttu neist eristub selgemini kirjutaja hääl. Arhiiviteadete kõrval on kasutatud ka veebiportaali BERTA (2004, http://www.folklore.ee/Berta) koondatud tänapäevamälestusi ja meediaintervjuusid - ühes folklooriarhiivi tekstidega võimaldavad need jälgida kombestikumuutusi diakroonilisel ja sünkroonilisel teljel.

\section{Traditsiooni muutumise põhjusi}

Rahvakalendri pikaaegse kujunemisprotsessi peamisteks mõjutajateks on olnud muutuvad loodus- ja majandusolud, poliitilised ja kiriklikud süsteemid, aga ka mood, meedia ja maitse, karismaatilised isiksused ja palju muud. Seetõttu on kalendrielemendid, nagu tähtpäevadega seotud kombestik, tabud ja lõbustused sajandite vältel muutunud. Lihavõtted põhilise kristliku kirikupühana peaksid eeldatavasti olema struktuurilt ja sisult väga püsivad ja järgima religioossete rituaalide üldreegleid ehk siis sagedase ühes ja samas vormis tähistamise tõttu olema kaitstud mälus moondumise eest. Vaatamata sellele, et rituaali iga uus esitamine sisaldab võimalust variaabluse sissetoomiseks, on mälestused regulaarse kordamise mõjul nii jõulised, et uued esitused pigem välistavad kui toetavad variatsioone. Religioossete rituaalide stabiilsusele aitab kaasa ka nende pekuliaarne avalik iseloom - need rituaalid nõuavad regulaarselt kollektiivset ja samaaegselt koordineeritud tegevust. Seesugune koordineeritus eeldab osavõtjate tegutsemist ja kuna religioossete rituaalide edu sõltub arvukate osavõtjate koostööst, piirab see asjaolu nende sooritamise vabadust. Teiseks on seesugused 
rituaalid seotud erilise kultuurilise esitusviisiga, mis ei tolereeri, vaid redutseerib rituaalide varieerumise (McCauley \& Lawson 2002: 50). Samuti kuuluvad lihavõttepühade kombed eelmainitud autorite liigituse järgi harva esitatavate korratavate rituaalide hulka (vt tabel 1 ).

Lihavõttepühade avaliku tähistamise viis erineb konfessiooniti. Eesti rahvakalendrile on enim mõju avaldanud katoliiklus, luterlus ja 19. sajandi teisest poolest alates peamiselt perifeerseil aladel ja linnades ka ortodoksne idakirik. Vanema, kristlikule kalendrisüsteemile eelnenud ajaarvamise ja tavade kohta võib teha üksnes oletusi.

Suurema murrangu põhjustas katoliikluse kehtestamine 13. sajandil, mis jagas aasta sümmeetrilisteks osadeks koos tähistatavate pühakupäevade süsteemiga. Kaasnenud kirikute ja kabelite ehitamine ning ristide püstitamine, samuti varasemate pühapaikade kujundamine katoliiklusele vastuvõetavateks külgnes uute pidustuste adapteerimise ja majandusviisi reformiga. Oletatavasti vahetasid sel ajal mitmed uskumusolendid nime ja muutusid nendega seotud rituaalide läbiviimise viis ning ohverdamistavad, suuri kive ja muid maastikuobjekte hakati seostama pühakutega. Katoliku kalendrikultuuri mõjud on nähtavad 16.-17. sajandi üleskirjutustest, reliktid aga tänaseski rahvakalendris, sh mõnevõrra säilinud sümmeetria, kus talvistele vastavad suvised pühakupäevad. Kuigi eesti rahvakalendri vanemas osas on säilinud rangelt piirkondlikke nähtusi, on enamik kombestikust ja sellega seotud mõtestamisviisist sarnane teiste Euroopa rahvaste traditsioonide ja pühadega, mis kohandatud siinsetesse looduslikesse oludesse.

Luterlik reformatsioon 1520. aastatel tähendas ühtaegu katoliiklike ja nn paganlike pühapaikade ümberkujundamise ja destruktureerimise algust. Taandus pühakutekultus, kujundati ümber rituaalide vorm. Kalendripäevade nimetuste, kirikunimede jm kaudu säilis aga seos varasema pühakutekultusega. Kuigi jutlusi peeti eesti kogudustele eesti keeles, olid nii linna- kui ka maakoguduste vaimulikud kuni 19. sajandi lõpuni valdavalt sakslased või lähedastest luterlikest maadest pärit õpetajad. Suurendas see koguduse ja õpetaja võõrandumist.

1840. aastatel algas poliitilisel ja majanduslikul survel üleminek õigeusku ja ka protestantlikesse vabakirikutesse, kuid peamiseks usutunnistuseks jäi luterlus. 1934. aasta rahvaloenduse andmeil pidas end luterlikku kirikusse kuuluvaks umbes 874000 inimest ehk neli viiendikku Eesti elanikest (Sild 1938; Plaat 2001).

Nagu viidatud, ei muutnud luterlik reform kogu senist kalendritavade süsteemi, ehkki tõi sinna uuendusi ja paljud tähtpäevad hakkasid ametliku toetuseta pöördumatult oma tähtsust kaotama. On aga märkimisväärne, et levitatav õigeusk (kinnistus eeskätt Eesti äärealadel ja linnades, vt nt Sõtšov 
Tabel 1. Rituaalide liigitus Robert N. McCauley ja E. Thomas Lawsoni (2002: 147) järgi

\begin{tabular}{l|l|l} 
& \multicolumn{1}{|c|}{ Sage } & \multicolumn{1}{c}{ Harv } \\
\hline $\begin{array}{l}\text { Korratavad spetsiaalse } \\
\text { patsiendi või spetsiaalse } \\
\text { instrumendiga rituaalid } \\
\text { (paarisarvulised tüübid) }\end{array}$ & $\begin{array}{l}\text { Sageli esitatavad } \\
\text { korratavad rituaalid }\end{array}$ & $\begin{array}{l}\text { Harva esitatavad } \\
\text { korratavad rituaalid }\end{array}$ \\
\hline $\begin{array}{l}\text { Mittekorratavad } \\
\text { spetsiaalse agendiga } \\
\text { rituaalid } \\
\text { (paarituarvulised tüübid) }\end{array}$ & $\begin{array}{l}\text { Sageli esitatavad } \\
\text { mittekorduvad rituaalid }\end{array}$ & $\begin{array}{l}\text { Harva esitatavad } \\
\text { mittekorratavad rituaalid }\end{array}$ \\
\hline
\end{tabular}

2004) ei toonud kaasa sügavamaid muutusi rahvatraditsioonides, rahvakalendris ja usuelus mujal kui Setumaal ja Kirde-Eestis, kus ortodoksne kirik tegutses juba pikemat aega ja oli ka varasemaid otsekontakte õigeusklike naabritega. Küll aga pakkus laienev õigeusu kirik nt luterlastele võimalusi jälgida ja osa saada teise konfessiooni rituaalidest (nt käigud õigeusklike kolmekuningapäevale).

Institutsionaalne, sh kiriklike ringkondade toetus ja ametliku tähtpäevakombestiku sümbioos rahvakombestikuga või vastupidi - kiriku vastuseis teatavaile tähtpäevadele ja nende pühitsemisele - on mõjutanud kalendritavasid rohkem, kui esmapilgul paistab. Märkigem veel, et 17. ja 18. sajandist alates hakkas Eestis rahvakalendrit mõjutama trükimeedia ehk kalendri- ja koolikirjandus, 19. sajandist alates ka spetsiaalsed trükialbumid, kalendripühadeks koostatud väljaanded ja ilukirjandus (vt jõulude kohta nt Viires 2002). Viimasel sajandil on meedia olnud võimas tähtpäevade juurutaja ja tähistamisviisi muutja, sellega on seotud nt valentinipäeva, emadepäeva, isadepäeva ja teiste pühade promotsioon.

Luterliku ja ortodoksse traditsiooni juurutamine oli seotud kindlate sihtrühmade poliitilis-majanduslike kaalutlustega. Eestlased läksid ortodoksesse riigikirikusse üle, lootes majanduskasu ja -leevendusi. Usuvahetuse motiivide kirevusest näiteks Jõhvi kihelkonnas saame ülevaate Eduard Tensmanni 1931. aastal kogutud ajaloolise pärimuse vahendusel:

Illukal on vene usku siirdumise mõjutajaks olnud Kuremäe lähedus. Kuremäel peetavatest jumalateenistustest võtnud rahvas suuremal arvul osa ning ka muidu on preestreil olnud kokkupuuteid ümberkaudse rahvaga, missugustel puhkudel nad olla katsunud rahvast meelitada (Juhan Vaabel).

Rahva seas olnud jutud, et vene usku siirdujaile antakse kõiksugu soodustusi. Neile antavat maad ja koolitatavat nende lapsed (Maria Klemets). 
Kiiklas olla räägitud, et vene usku minejad saavad 25 rubla. Esimesed minejad olla ka saanud(!), hiljem aga, kui suuremal arvul hakatud end ristida laskma, pole enam antud (Jakob Hindreus).

Ühes perekonnas olnud laps haige. Preester öelnud, et kui ta vene usku ristitakse, siis ta saavat terveks. Vanemad ollagi lapse lasknud ristida vene usku ja ta saanud ka terveks. Täiskasvanuks saades poiss olla end lasknud ristida uuesti luteri usku (Mihkel Mamun).

Järvel olla mõned noormehed end lasknud ristida vene usku sellepärast, et siis pole vaja leeri minna ja lugemist óppida (nad pole oskanud lugeda) (Samuel Samuel).

Konjust olla mitu peremeest sellepärast end ristida lasknud, et aetud Jõhvi surnuaia mü̈̈rile kive vedama. Vene usku minnes pole olnud vaja minna (Joosep Karukäpp).

Ka pääle selle, kui postimaks jälle uuesti sisse säetud, läinud mõned, selle üle vihastades, vene usku (Tensmann 2005 [1931]).

Niisiis olid mõjutajateks eespool nimetatud lootused pikemaaegsetele leevendustele ja soodustustele, ajutine pääs töökoormistest, varasem tutvus idakirikuga, valikud kriisisituatsioonis, aga selgesti ilmneb ka varasemast märgatavalt vabam võimalus valida koguduste vahel.

Poliitilise võimu mõju pärimusele on selgelt kirjeldatav möödunud sajandi näitel. Teise maailmasõja järel destruktureeris nõukogude võim rahvalike pühade süsteemi, osa ebasoosingus kombestikust nihkus avalikust sfäärist koduseinte vahele. Osalt sekulariseerumis- ja individualiseerumisprotsessist, osalt poliitilisest survest tulenevalt privaatseks perepühaks kujunenud tähtpäevade hulka kuulusid ka lihavõtted ja suvisted. Rahvusliku eneseteadvuse tõusud ja langusedki on õhutanud vanu kombeid taasavastama või unustama.

\section{Lihavõtted sajandite jooksul}

USA religiooniloolase Catherine Belli sõnutsi on rituaalide süsteemi sisemise korra näol enamasti tegemist standardsete opositsioonide keeruka harmoonilise orkestreeringuga, millest tekivad paindlikud suhtekogumid, mis nii eristavad kui ka integreerivad tegevusi, pühakohti ja kogukondi. Kodused kombetalitused vastanduvad kogukondlikele kombetalitustele, meeste omad naiste omadele, algust tähistavad kulmineerivatele. Strateegilised erinevused pärimuslikes kombetalitustes võivad olla teatud kogukondade eristajaks, rituaalide loomine võib toimida ka kogukondade integreerijana (Bell 1992).

Nagu eespool viidatud, on varasema kalendritavandi jälgimiseks vähe allikaid, kusjuures eelisolukorras on olnud linnarahvas, eriti kõrg- ja kesk- 
klassi liikmed, mis tähendab, et jäädvustati eeskätt mitte-eestlaste ja ümberrahvustunud eestlaste tavasid. Seevastu 19. sajandil tervikuna ja 20. sajandi esimesel poolel on eelisolukorras olnud maarahvas. Kalendritavade juures oli palju avalikus ruumis toimuvat tegevust ja sümboleid, millest saadi osa ja mida jäljendati isiklikus ruumis. Lähtudes eeldusest, et erinevate sotsiaalsetes klasside vahel ei olnud jäika infobarjääri, vaid teadmised ja traditsioonid liikusid erinevate informaalsete võrgustike kaudu neisse kuuluvate isikute vahel, võime laiendada neid andmeid teatava piirini ka teistes rühmades toimunule.

Anu Männi keskaja pidustuste uurimus võimaldab jälgida suuremate pühade tähistamist: 14 . sajandi nelja tähtsama avalike jootude ja pidutsemisega tähistatud püha hulka kuulusid mardipäev, jõulud, vastlad ja lihavõtted. Õlu ja vein kuulusid aga ka mihklipäeva ja paastuaja, Liivimaal jaanipäeva ja mõnede pühakute päevade pühitsemise juurde. 15. sajandil nimetati tähtsamate rahvakalendripühadena jõulusid ja vastlaid, kusjuures vastlapidustusteaegsed kulutused meelelahutusele ja gildipidudele olid enamasti suuremad kui jõulude ajal. Alates 15. sajandist kerkisid esile uued pühad, mille sekka tõusis uusaasta ja ainsa eestikeelse nimetusega pühana hingepewe ehk kõigi pühakute päev.

Keskajal tähistati lihavõtteid päeva vältel, kui Tallinna ja Riia raeliikmed kogunesid raekotta õlut ja veini jooma. Keskaja pidustuste uurija Anu Mänd osundab, et kaks vaati tumedat õlut varuti lihavõtete tähistamiseks aastal 1372, seevastu vaat õlut kulus Tallinna Suures Gildis juba aastal 1363 (Mänd 2004: 66). On teada, et pidustustel lauldi ja et see oli linnamuusikutele palgamaksmise päev. Veel 15. ja 16. sajandil oli rahval kombeks koguneda Tallinna raekoja juurde veini ja õlut jooma, pidutsemine toimus lihavõtteile järgneval perioodil. On teateid õlle ja veini varumisest paastuajaks, samuti ei olnud lihavõtted üksnes muusikutele tasumise aeg, vaid üldiselt tähtis majanduslik daatum maksude ja võlgade tasumiseks. Keskajal privaatses keskkonnas toimunust teateid ei ole, rituaalne kese oli kirik ja arvatavalt värvikad pidustused peeti avalikes paikades.

Kui üritame jagada aasta kriitilisteks perioodideks, leiame rahvausundi teadete põhjal kindlad vahemikud, millal mütoloogilised olendid ja üleloomulikud jõud aktiivselt liiguvad ehk neli aktiviseerumisaega pööripäevade ümbruses. See vastab ka kristlikule õpetusele kurjade jõudude ja kuradi erilisest aktiivsusest pöördelistel tähtpäevadel. Näiteks usuti, et lapsest, keda on imetatud kolm suurt neljapäeva (alternatiivina - kolm aastat), kasvab nõid.

Rahvapärased seisukohad aastaaegade pikkusest erinevad kalendris fikseerituist ja nende kohaselt on talv suvest oluliselt pikem. Keskaegse jaotuse järgi jagati aasta neljaks talviseks ja kolmeks suviseks perioodiks ehk 
õueks. Talveõuede perioodile (kestsid mihklipäevast ülestõusmispühadeni) langes 19. sajandil olulisi kriitilisi piiridaatumeid rohkem kui nn suveõuedele. Näiteks loitsimise kohta on enam teateid mihklipäeva, mardipäeva, jõulude, madisepäeva, suure neljapäeva ja suure reede, suvepoolelt jüripäeva, nelipühade ja jaanipäeva kohta (Kõiva 1990: 175). Seega püsis jätkuvalt nn talveõue kriitiliste daatumite ülekaal.

17.-19. sajandini leiame kirjandusest nurisemist kirikutähtpäevadel nõidumise ja viljakuse taotlemise üle (nt Russow 1993; Westrén-Doll 1926). Suur neljapäev ja suur reede on hilissajandeil sobinud eriti väiksemate maagiliste rituaalide abil eelseisva aasta edu mõjutamiseks. 19. sajandi ajakirjanduses avaldati teateid rahvakommete tähistamisest avalikus ruumis, arhiiviteated kõnelevad privaatsest tähistamisest. Lihavõtted on nende teadete kohaselt sümbioos aastaajale omastest mälestamis- ja religioossetest pühitsemistest (Bell 1997: $103 \mathrm{jj}$ ), millele lisandub sotsiaalsete sidemete kinnitamine.

Populaarseim Euroopa ja loomulikult ka Eesti lihavõttekomme oli munade - rahvakultuuri põhiline asjakohane sümbol - värvimine, kinkimine, söömine; Lõuna-Eesti ortodokssetele aladele oli tunnuslik munaveeretamine.

Kultuurisotsioloog Arjun Appadurai (1986: 5) sõnutsi puudub asjadel igasugune tähendus peale selle, mille inimeste tehingud, omistused ja motivatsioon nendele annavad. Lihavõttemunad on olnud märkimisväärne sotsiaalse suhtlemise vorm - neid vahetati ja saadi kinkidena. Kui 19. sajandi teated räägivad pikemaaegsest munade varumisest, et neid jätkuks värvimiseks ja jagamiseks oma perele, sugulastele ning munadeotsijatele, samuti püüdest, et neid ei oleks piinlikult vähe, siis 20 . sajandil toimub kanafarmide arengu ja uuema kaubasüsteemi mõjul murrang - munade hankimine on lihtsam, neid jagatakse heldemalt.

On märgatavad ka muutused munade kui lihavõttepühade ja kodukultuuri sümboli maines ja olulisuses. Tänapäeval antakse mune sõpradele, õpetajatele, töökaaslastele, samuti ämmaemandatele ja ristivanematele, kes varasema kombe kohaselt pidid hoopis ise ristilastele mune kinkima. Seega on kinkimine nihkunud sugulastelt aina laiemasse ringi - isikuteni, kellega seovad sõprus- või tööalased suhted. Ka on munavahetajate vanus noorenenud - 19. sajandil ja 20. sajandi esimesel poolel olid need tavaliselt noormehed ja neiud, samuti oli ristivanematel tavaks ristilastele mune kinkida. Nende täisealiseks saades eeldati, et ristilapsed annavad mune oma ristivanematele. Kombestiku vahendusel on jälgitavad kunagised erinevad nõuded noortele ja vanadele, tunnustus- ja sümpaatiaavaldused. Sajandi teisel poolel vanuseline diapasoon laieneb, suureneb orienteeritus lastele ja nende kui kinkijate osatähtsus.

Suurbritannia folklorist Jacqueline Simpson on rõhutanud, et mitmed kalendripühad on olnud suunatud lastele ja selletõttu on säilinud lastega 
peredes mitmekülgsemad tavad (Simpson \& Roud 2000), mis on kahtlemata arvestatav ka lihavõtete puhul. Lastega koos munade värvimise tava kuulub pigem 20. sajandisse, kuid siitpeale on laste olulisus tavandis selgelt jälgitav. 1960.-1970. aastatel ja hiljem nihkus värvimine rohkem noorperede, laste ja teismeliste traditsiooni. Lastega koos munade värvimine ning jagamine sõpradele ja sugulastele oli sügavalt privaatne perekomme, seda eriti nõukogude ajal, kui kiriklik lihavõtete tähistamine oli riigi poolt taunitud. Järgnev Iisakust üleskirjutatud tekst annab ülevaate 20. sajandi alguse värvikast nooremate inimeste kombestikust:

Kevadepühade ajal ruttasime ikka kiriku, seal sai noorematega kokku. Muidu ei lubatud külla. Munad keedeti, värviti ja anti ristilastele. Ristiema andis ristilapsele, kuni see läks leeri. Pääle leeri annab ristilaps ristiemale kas kompvekki või muud. Poisid käisid külas tüdrukute juures mune otsimas. Poisid tulid troppis. Anti ikka tuttavatele ning ka võõrastele.

Vaikla külas käisid poisid ja mehed kukeks. Enne päikesetõusu, oli säetud kuke moodi ja laulab kukeleegu, siis tead, et pead muna andma.

Lihavõttemunad olid punased ja kirjud, aga nelipühi olid kollased, kaselehtedega värvitud. Värvitud mune viidi sipelgapessa, et need teeksid kirjuks. Siis oli munal hea lõhn ja ka hea maitse. Neid mune anti ainult kõige parematele sõpradele (RKM II 142, 420/1 (11) < Iisaku khk, Kauksi k - Erna ja Herbert Tampere < Johannes Anijärv, 63 a, ja Johanna Anijärv, 59 a (1962)).

Mainigem, et lihavõtete kõrval (värvimise ja vahetamise strateegia oli tuntud kogu Eestis) värviti ja vahetati Põhja- ja Kesk-Eestis mune veel nelipühade ehk suvistete ajal.

Rohked üleskirjutused ja meediaväljaanded võimaldavad jälgida väiksemaidki muutusi pühitsemises ning vanemate kommete erinevatel põhjustel naasmisi. Näiteks lihavõttemunade kaunistamiseks oli erinevaid võimalusi, mis moe ja innovatsioonide kõrval on olnud tihedalt seotud majandus- ja kaubandusoludega. Tänini on tavaline looduslike ainete, nt sibulakoorte (pruunid ja kollased munad), kase(viha)lehtede (helekollased), madara (punased) ja kohviga (pruunid) värvimine, mis eeldab enamasti värvimisvahendite varumist ehk siis pikemat pühadele orienteeritud käitumist. 20. sajandil kasutati värvimiseks krepp-paberisse ja riideribadesse mähitult keetmist; mustrite, täppide jm saavutamiseks aga puistati riide või paberi alla muna peale riisi või tangu. Kaunistamisvõtetest on tuntud veel munakoorele saaja nime või salmikese kriipimine või kirjutamine, kuid ka piltide joonistamine või kleepimine. Kasutati ka vaha abil mustrite tegemist või siis taimevarsi ja õisi, et 
tekitada koorele õrn taimekujutis. Koos õppekavade ja -vahendite muutumisega levis värvimine vesivärvide ja guaššidega, mis koolilastel olid nagunii kodus olemas, eelistatavalt kasutati muidugi spetsiaalseid munalakke. Niisiis liikusid laste kaudu majapidamisse uuemad värvimisvahendid; koolide, käsitööringide ja meedia kaudu juurdus uuenduslikke võtteid. 1970. aastate ja hilisema nõukogude kaubadefitsiidi perioodil tõusid uuesti ausse traditsioonilised sajandialguse värvimisvahendid, kuid kasutati loomulikult kõike kättesaadavat, sh apteekides müüdavat kaaliumpermanganaati ja briljantrohelist. Sajandi lõpukümnendi vabakaubanduse tingimustes taastus ja arenes edasi sajandi alguses harrastatud munavärvimistehnikate mitmekesisus: hõordepildid (vesipildid) ja kleepsud, väljalõiked, liimitavad lisadetailid, suled, nagu ka munade kujundamine tibudeks, jänesteks või koomilisteks inim- ja loomakujudeks - kõigeks, mida valmistaja suutis välja mõtelda. Ka armsama või kinkemuna adressaadi nime kirjutamine, südame või muu lihtsa sümboli kujutamine oli sajandi algus- ja lõpukümnendeil laiemalt levinud.

Esimesed dokumenteeringud lihavõttejänesest pärinevad Saksamaalt aastast 1572. 19. sajandil levis Eestis munade peitmine lastele otsimiseks ja tava säilitada mõnda kaunist lihavõttemuna kodukaunistusena pikemat aega. Usuti, et hoolikalt hoitud lihavõttemuna rebu hakkab seitsme aasta pärast kumama, koor muutub läbipaistvaks. Munade värvimine ja korterisse, majja või aeda peitmine, samuti spetsiaalselt lihavõttepühadeks samblaga vooderdatud pessa või rohelisele orasele asetamine muutus möödunud sajandil Eesti kodukultuuri tunnuseks. Levis lastele suunatud pärimus ja lasteuskumused lihavõttejänesest, kes toob öösel salaja mune ja peidab need.

Mäletan lapsepõlvest, et unistus tabada lihavõttejänes mune toomas oli sama ehe kui soov sattuda kokku kinketoova jõulu- või näärivanaga. 1960. aastatest alates on kodusele lihavõttelauale lisandunud šokolaadimunad ja ümmargused väikesed kompvekid (nt rosin šokolaadis), mida lihavõttejänest tundvad rahvad kutsuvad jänesepabulateks. Umbes samal ajal hakati värvitud munade asemel peitma ja kinkimagi šokolaadi- ja martsipanmune jm -kujusid.

Kombestiku puhul on esile toodud, et selle sage kordamine tagab usaldusväärse mäletamise, kuid kultuuriliselt võib tihe kordamine kahandada tähelepanu nähtuse vastu - kaob huvi või siis reinterpreteeritakse rituaal (McCauley \& Lawson 2002: 50). Lihavõttekombestiku mängulisus, sh fiktiivsete narratiivide loomine, erinevad maskeerimisvormid, nagu ka sotsiaalne interaktsioon muudavad pühad osaliste jaoks unikaalseks. Uuenduste hulka kuuluvad 20. sajandi lõpul linnades jalutanud jänesekostüümides seltskonnad või vastavalt riietatud institutsioonide munamüüjad ja lastelõbustajad, kui ka eelmise sajandi traditsioon saata pühadeõnnitlustega postkaarte. 


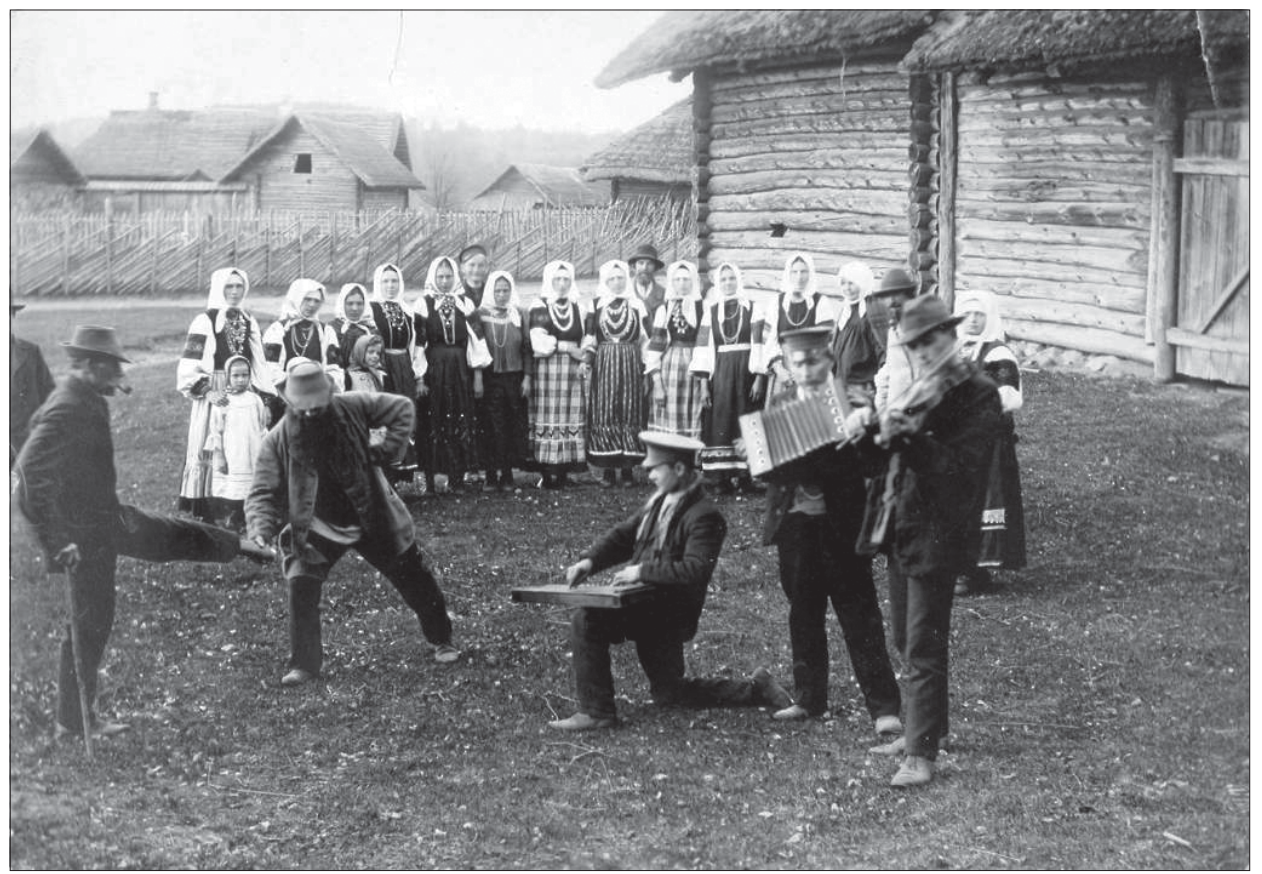

Foto 1. Lihavõttepühade lõbustused Setumaal Võmorska külatänavas 1913. aastal. Noorte meeste nalja ja pillimängu vaatavad setu naised eemalt. Johannes Pääsukese foto. Eesti Rahva Muиseumi fotokogu 213:167.

Eesti varasemate lihavõttekaartide traditsioonilised sümbolid on tibupojad või lihavõttejänes värvitud munadega ja pajutibud. Esimesed trükipostkaardid valmistati Saksamaal ja nad sarnanevad tollasele üldisele toodangule (BERTA 2004: Lihavõtted). Isevalmistatud postkaarte - nende kujundus varieerub rohkem - hakati saatma ja valmistama Teise maailmasõja ajal ja järel, sest nõukogude ajal ei olnud lihavõtete tähistamine avalikult soovitav ja vastavaid postkaarte Eestis enam ei trükitud. Kaartide saatmine kuulus lahutamatult perekultuuri juurde, mistõttu asendusena kasutati fotograafide poolt mahapildistatud, osalt koloreeritud sõjaeelseid kaarte. 1941. ja 1949. aastal küüditatud eestlased saatsid vangilaagritest omajoonistatud kaarte, nii nagu ka teise keskse püha, jõulude ajal. Samuti talitasid Läände pagenud diasporaa-eestlased, kellel ei olnud emakeelseid kaarte võimalik kusagilt osta. Käsitsi joonistatud ja ise kujundatud lihavõttekaarte on alati valmistanud loomulikult ka lapsed - see on üks lasteaedade ja koolide vahendusel taas elavnenud kombeid. Seesugused kaardid muudab kõigil aegadel eriliseks nende kõrgem sotsiaalne ja sümboolne väärtus - oma isikupäraga on nad emotsionaalse sideme, isikliku tähelepanu ja hoolimise märk. Nende tänapäevased asendajad e-mailid, e-kaardid ja SMS- 
sõnumid on kujunduselt postkaartidega sama stereotüüpsed, erinedes veebikunsti varasemal perioodil omakäeliselt kujundatud ASCII-piltidest ja õnnitlustest, mille loomine sõltus isiklikest oskustest ja tahtest.

Laiemalt levinud uskumuse kohaselt tantsib päike lihavõttepühade hommikul tõusmise ajal (vrd Simpson \& Roud 2000; Šmidts 1940-1941), mida koguneti õue, mäetippudele või ärklikorrusele jälgima. Peretraditsioonide juurde kuulus möödunud sajandil varasematest kommetest varahommikuse päikesemängu jälgimise kõrval pühadeks okste või pajutibude tuppa toomine. Oksi ajatati talvelgi, kuid tingimata lihavõteteks. 20. sajandi alguses hakati kasvatama murulapikesi. Kui sinililled juba õitsesid, toodi tuppa kevadõisi koos samblaga. 19. sajandi lõpul ja 20. sajandi alguses viidi palmipuudepüha ja lihavõtteteenistuse ajal õigeusu kirikusse õnnistamisele pajutibusid, millega urbiti kodus pereliikmeid, vastu saadi pisikesi kinke.

Vanade uskumuste kohaselt muutus vesi allikates ja kaevudes minutiks magusaks, selle uskumuse jätkuna lähetati mõnel pool lapsi allikasse või kaevu suhkrut viskama.

Kevadpühade esimese püha hommikul äratas üldist tähelepanu nn päikesemäng. Kui tahtsid seda näha, pidid päevatõusuks katsuma kobida voodist. Siis päikeses pidid ristlema imeilusad kullakad kiired, läbisegi, korratult, mis pidi olema eriti huvitav. Kuid kahjuks nägi seda huviküllast mängu ainult siis, kui oli selge ilm ja iga kord mitte ka selge ilmaga (E 73060 (5) $<$ Karja khk, Pärsamaa v, Ratla k - P. Tamm < Tiiu Lodi (1931).

\section{Maskeerimistavad}

Sarnaselt teistele reformatsiooni järgivatele Euroopa maadele hakkas uusajal Eestiski karnevalitraditsioon asenduma maskeerimis- ja sanditamistavade ning muude avalike tegevustega, millest lähemalt allpool. 19. sajand oli maskeerimistavade rohkuse ja perioodi pikkuse poolest märkimisväärne. Enamik maskeerimiskombestikuga seotud tähtpäevi jäi vahemikku novembrist kolmekuningapäevani, järgnes lihavõteteaegne maskeerimine.

Kogu Eestis (v.a ortodoksne Kagu-Eesti) oli rikkaliku kombestiku ja lokaalsete erijoontega maskeerimise kõrgaeg mardipäeval (10. november) ja kadripäeval (25. november), õigupoolest liikusid andide kogujad ringi mõlema päeva laupäeval. Juba 19. sajandil oli eriti rikkalik Lääne-Eesti ja saarte maskeerimiskombestik, millel oli ühisjooni Skandinaavia vastavate tavadega (jõulu- ja näärisokud, andresed, nuudid jt, vt Eike 2002) või laiemalt levinud tavadega, nagu kolm kuningat (Simpson \& Roud 2000). Varem laiemalt tuntud lihavõteteaegne maskeerimine säilis ennekõike läänepoolsetel aladel, ilmselt toetatu- 
Foto 2. Isevalmistatud lihavõttekaart. Erakogu.
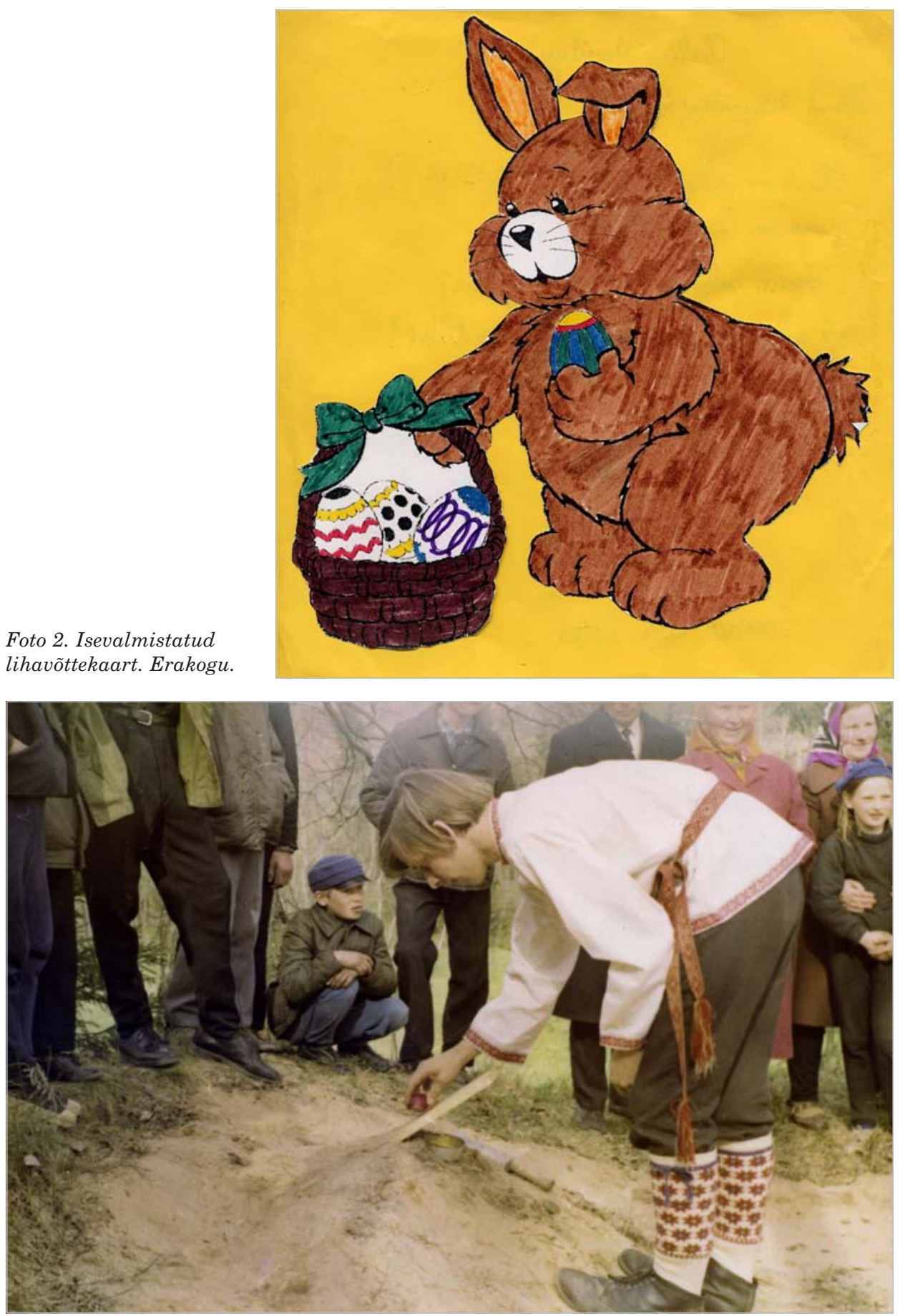

Foto 3. Munade veeretamine Setumaal Lepa külas 1975. aastal. Vello Kutsari foto. Eesti Rahva Muuseumi fotokogu 1754:16. 


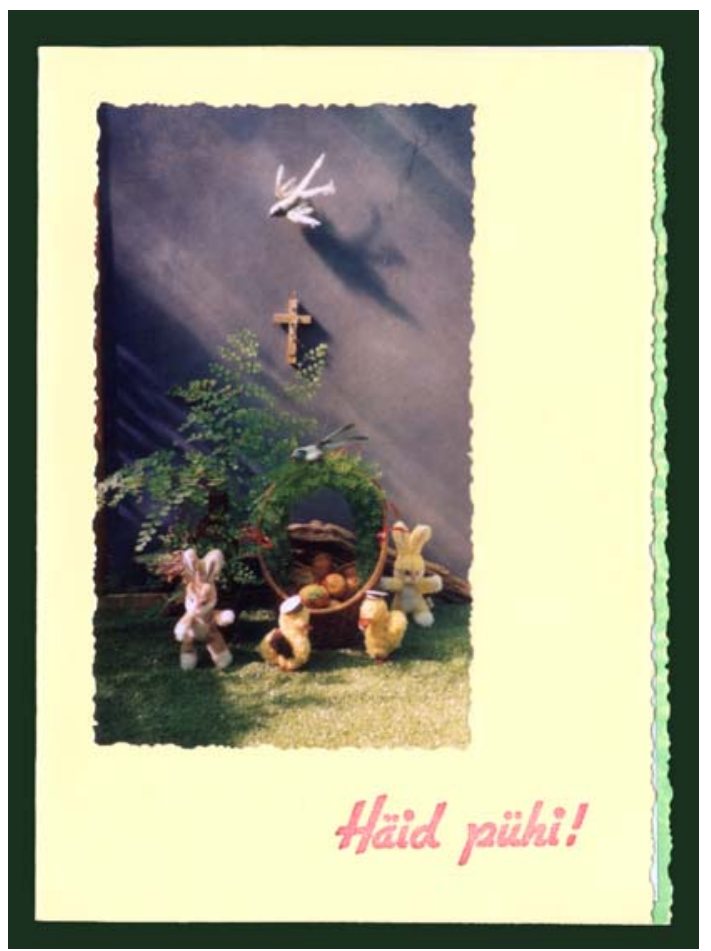

Foto 4. Rõõmsaid lihavõttepühi 1979. Austraaliast Brisbane'ist kodumaale saadetud omatehtud lihavõttekaart. Erakogu.

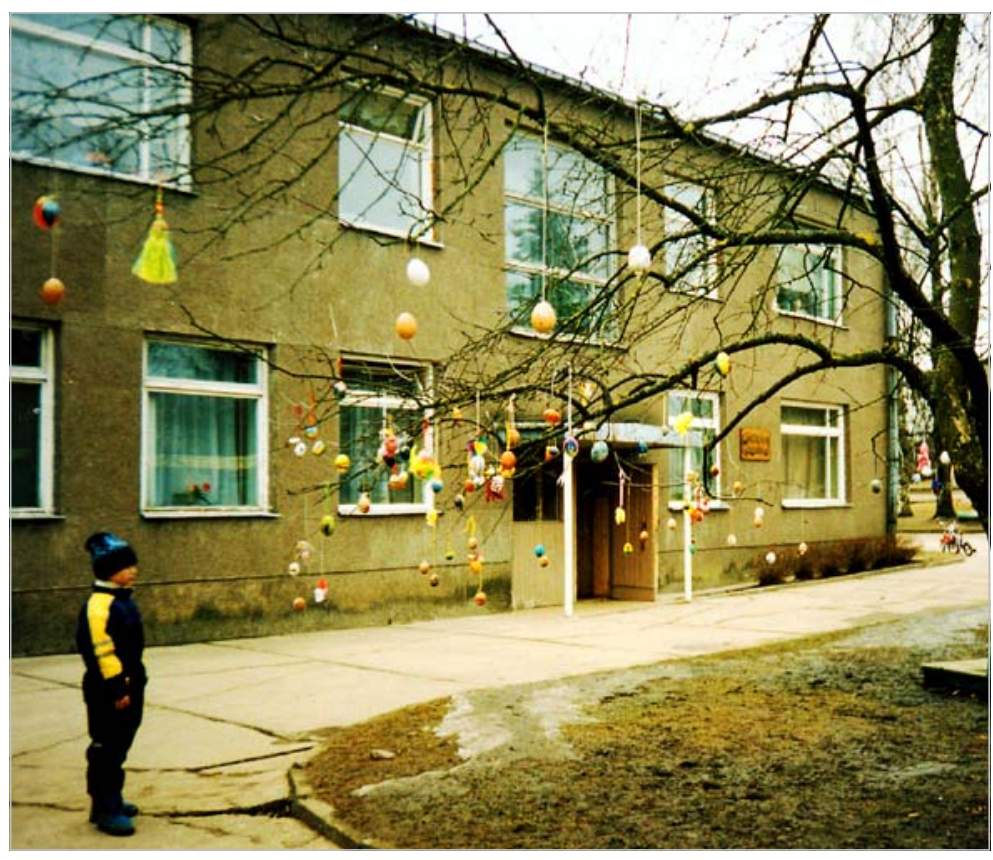

Foto 5. Lasteaiad tähistavad ülestõusmispühi munavärvimise ja kontserdiga. Tartu lasteaia Rukkilill lapsed ja kasvatajad ehtisid 2002. aasta pühadeks oma õue puud värviliste munadega. 
na teiste tähtpäevade sarnasest kombestikust. Samas piirkonnas olid tavaks loomaks või linnuks maskeerunute külaskäigud hea tervise soovimiseks. Näiteks suurel neljapäeval ja suurel reedel käis hani kasevitsaga külas vitsa andmas ja head tervist soovimas. Hilisteadetes ei riietutud enam haneks, kuid säilis tava teda niiviisi kutsuda. Kukkedest oli juttu näitetekstis.

Omapärane maskeeritu oli Lihaeit või Liha-Kai, kelle kohta on teateid taas 19. sajandist. Tegemist oli paastu personifikatsiooniga, keda usuti jälgivat paastumist, ja töökeeldude, eriti kudumistöö keelu järgimist. Iseloomult sarnanes see uusaastaaegse ringirändava nälja personifikatsiooniga, kes samuti üritas piiluda toas toimuvat. Rahvapärase didaktilise ütluse kohaselt murrab Lihaeit töökeeldudest üleastujal kaela ja kisub soolikad välja.

Ei ole päris selge, miks kadus lihavõteteaegne maskeerimistava kiiremini kui muudel tähtpäevadel. Kas oli põhjuseks uskumussüsteem, mis takistas traditsiooni üleminekut naistele ja lastele, kelle vahendusel paljud pärimuslikud tegevused püsima jäid? Paljudes Euroopa maades käisid lihavõtete ajal lauldes ringi lapsed. Eestis peeti 19. sajandil halvaendeliseks, kui kriitilisel perioodil oli esimene külaline või vastutuleja naine. Selle välistamiseks saadeti või käisid noormehed külas õlut küsimas ja pühade saabumise puhul tervitamas. Lihavõtete ajal olid keelatud laste külaskäigud - neile visati sellest üleastumisel pastlad või vana kingapaar kaela. Alles eelmise sajandi lõpukümnendeil, kombe hääbumise ajal, hakkasid näiteks näärisokuks maskeerinud mehi nende läbiküla teekonnal saatma naised, jäädes ikkagi maskeeritute selja taha või õue, üldiselt jäigi jõulukuine maskeerimine täiskasvanud meeste privileegiks. Võib-olla põhjustas hääbumise ka asjaolu, et kevadine maskeerimine jäi erandlikuna ajaliselt liiga kaugele sügistalvisest maskeerimise kõrgajast, kiikumishooaja alguse jm tõttu leidus aga muidki lõbutsemisviise.

\section{Kommunikatsioon ja lokaalsuse loomine}

Eelnevatest kirjeldusest ilmnes, kui oluline osa oli lihavõttemunadel sugulaste, naabrite, sõprade jt vahelises kommunikatsioonis. Ajastukohaseks erijooneks Teise maailmasõja eel ja selle järel oli noormeeste-külapoiste levinud meelelahutus - rühmana munade otsimine. Sajandi alguses koguti rahvaluulearhiivi teateil küla pealt tihti korvitäis mune, nii et poisid on kurtnud raskusi kogutu ärasöömisel. Tütarlastel oli tavaks kinkida kaunimad munad lemmikutele või armsamale, poisid kinkisid oma lemmikutele mune vastu. Paljudes piirkondades kogunesid noored seejärel tantsu- või ühisele munasöömise õhtule. 
Sümpaatia ja lugupidamise avaldamise ning sugulussidemete väljendamise kõrval demonstreeriti munade vahendusel ka antipaatiat ja naeruvääristati inimesi, kellega ei olnud head läbisaamist. Üheks viisiks oli ebameeldivale munaotsijale kehvemini õnnestunud või toorelt värvitud munade kinkimine. Munakoksimisel oli toore muna avastamine üsna häbistav. Teine levinud trikk oli puumunaga koksimisvõistluses osalemine - meisterlikult värvitud muna ei eristunud keedumunast.

Mune värviti ja siis tehti külale ring peale. Täismehed olid ka kampas ja otsiti mune tüdrukute käest. Pärast jälle trikseldi, et kellel muna katki läheb, see peab oma muna andma ära sellele, kellega triksles. Ühel oli trikslemisel korra puumuna kaasas, ära värvitud ja. Küll sai teistelt mune kätte. Poisid a'asid küll peale, et näita oma muna lähemalt, aga ei näidanud.

Üks matnu oma munasaagi sambla sisse maha, et pärast tuleb järgi. Pärast ei leidnud enam mune üles. Vahest mõni teine leidis jälle teise munad üles taga ja viis minema. Sellega nalja sai.

Vanasti mindi kõrtsi ja seal siis trikseldi (RKM II 362, $456(16)<$ Otepää khk, Palupera v, Mõrtsuka k, Järva t - Mare Kõiva < Rudolf Andrei, s 1908 (1982)).

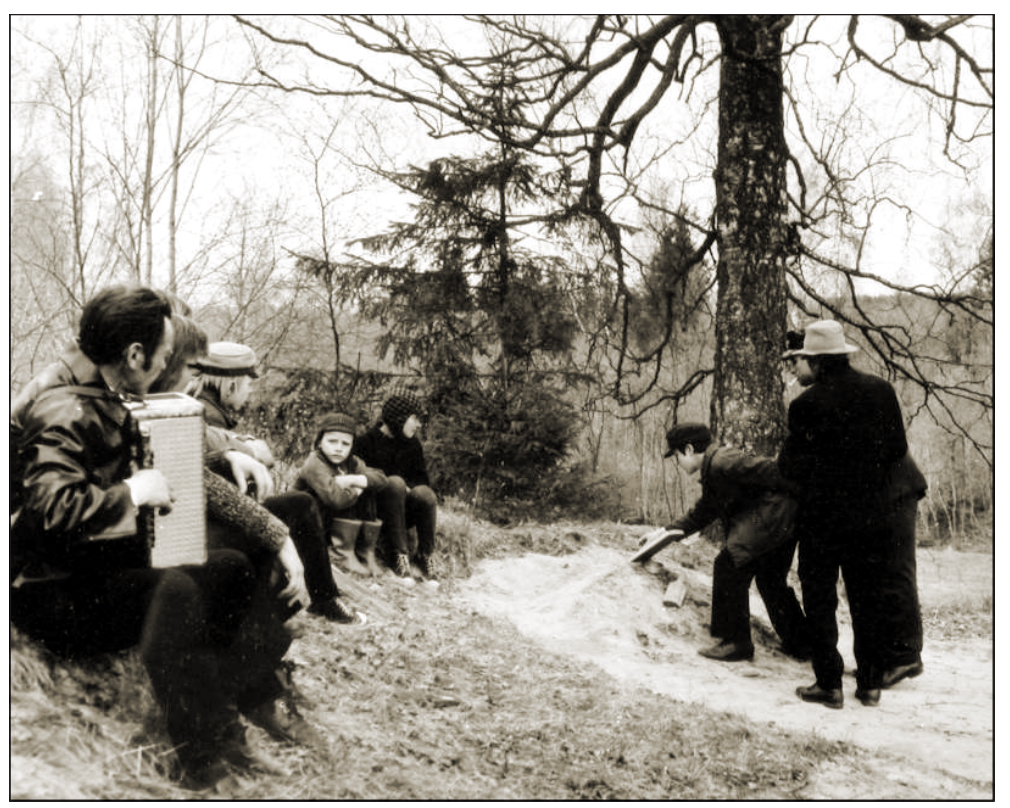

Foto 6. Munaveeretamine Setumaal Lepa külas 1975. aastal. Vello Kutsari foto. Eesti Rahva Muuseumi fotokogu 1754:20. 


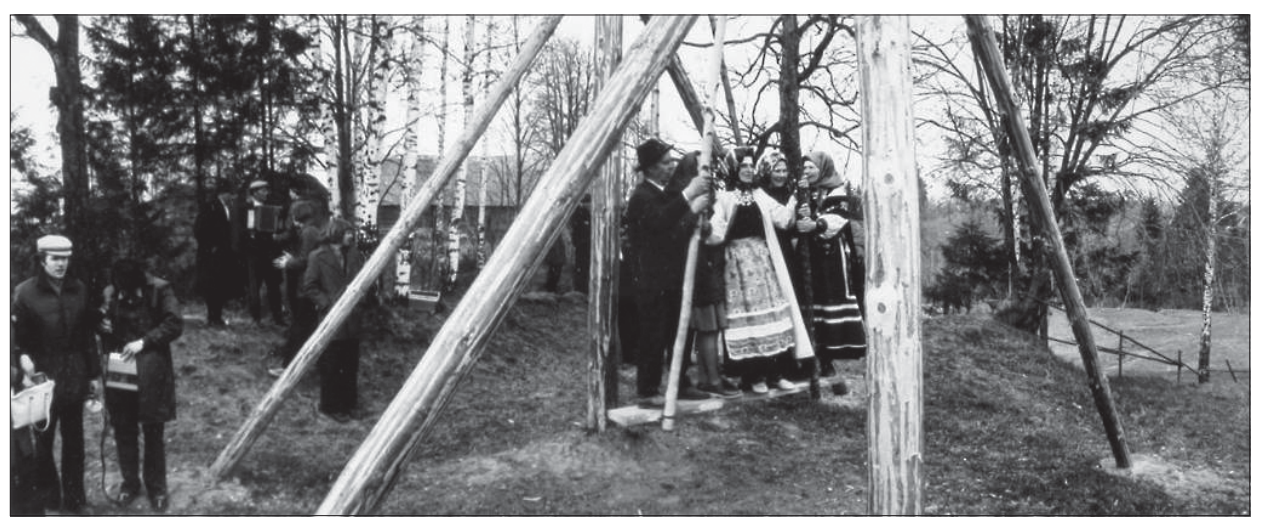

Foto 7. Lihavõtted Setumaal Lepa külas 1975. aastal. Naised kiigel. Vello Kutsari foto. Eesti Rahva Muuseumi fotokogu 1754:3.

Tüdrukute ja poiste suhete väljendamise juurde kuulus ka munade lõhkumine. Tüdrukute õrritamiseks litsuti nende kaasavõetud munad laiaks, mis jättis ohvri võimaluseta täita omapoolne osa tähtpäeva olulises kommunikatsioonis.

Kui munade koksimine oli populaarne ja laialt levinud komme nii väljaspool kodu kui ka koduseinte vahel, siis Kagu-Eesti munaveeretamine kuulus avalikult tähistatava külapüha juurde. Kuna sel perioodil algas Lõuna-Eestis kiikumisperiood, koguneti kiige juurde peole kiikuma, laulma, tantsima, ühiselt kodusvalmistatud pühadetoite maitsma ja vestlema. Tehniliselt sarnaneb Kagu-Eestis munaveeretamine šoti tavaga (Lyle 1998). Mune veeretati Setumaal piki erilist puurenni ehk munaloomkat. Kelle muna puudutas teise oma, võitis selle endale. Veeretamist sai jätkata võiduõnne pöördumiseni, seejärel loovutati järjekord järgmisele isikule. Võidetud munad söödi kohapeal, kuigi võitja võis need ka koju viia. Munaveeretamine ja kogumine oli sealses piirkonnas meeste komme, ent viimastel kümnenditel on tava liberaliseerunud, mistõttu ka naised proovivad osavuses kätt. Kombestiku modifitseerumisel ja rangete soorollide leevenemisel on mitmeid põhjusi, sh läbikäimine luterliku taustaga naabritega, kus ranget soolist polariseerimist ei järgitud, üldine sekulariseerumine ja naiste sotsiaalse staatuse muutumine kogukonnas viimase poolsajandi jooksul jpm.

Väljapoole ajaloolist asuala elama siirdunud kagueestlased on püüdnud oma kombestiku erijooni säilitada. Munaveeretamisest kui muu Eesti rituaalipraktikast põikuvast kombest kujunes väljarännanute kohaidentiteedi väljendus - seda järgiti linnakorteris või õues mune veeretades. Kommet on jätkatud eeskätt lastega peredes ja laste jaoks, kusjuures ema oli enamasti traditsiooni säilitaja - munade värvija, peitja ja veeretamise al- 
gataja. Ka on setu seltsid ja noorteühing korraldanud väljaspool Kagu-Eestit avalikke munaveeretamisi, osavõtjateks sealse taustaga inimesed, kultuurihuvilised ja sõbrad. Sel kombel on eripärasest lihavõttekombestikust külapühade kõrval kujunenud lokaalse identiteedi element, nähtus, mis aitab eristada oma kultuurirühma teistest.

Sajandite jooksul on lihavõtteid iseloomustanud rohke välistegevus ja avalik tähistamine. Nagu mainitud, oli see Lõuna-Eestis veel Teise maailmasõja järel kiikumisaja alguse marker. Varasematel aegadel oli kiikumise algus ja lõpp ajaliselt täpselt määratletud ja sellega seotud tegevus kandis maagilist tähendust (Vissel 2003: 35). Lihavõtteaegne (maagilise eesmärgiga) kiikumine oli levinud kõigil läänemeresoomlastel, samuti baltlastel ja venelastel (Talve 1961: 33-36). Kuna kiikumise algus langes tähtsale pühale, sümboliseeris see tervise, elujõu ja õnne taotlemist perele ja karjale. 19. sajandil oli külakiige ehitamine noorte meeste ülesanne, kiigeseppadele tasuti kinnaste, vööde ja tingimata ka munadega. Noorte meelelahutuste hulgas oli kiik(umine) ja selle ümbrus erakordselt oluline paik seal lauldi, mängiti, katsuti jõudu ja tantsiti vähemalt südasuveni, hiljem pikemaltki.

Põhja- ja Kesk-Eestis hüpati lihavõtte ajal lauda. Seegi noorte ja laste osavusmäng kandus hiljem laste suviste meelelahutuste hulka, sest nõudis vähe vahendeid. Kivile, kännule või pakule asetatud laua kummaski otsas seisjad hüppasid kordamööda õhku, oluline oli säilitada tasakaal ja õige hüppamisrütm (vt lähemalt Vissel 2003: 19 jj). Tänaseni harrastatav meelelahutus pidi samuti tagama tervise.

\section{Kadunud tavad: väikeriitused ja hea õnne tagamine}

Sarnaselt teiste oluliste pühadega, nagu uusaasta, suvisted ja jaanipäev, oli lihavõtete ajal keelatud tubade puhastamine ja põrandate pühkimine - suureks pühaks valmistuti enne seda põhjalikult. Vaikse nädala ja lihavõtete ajal toimetati veel 20. sajandi alguses mitmesuguseid väikesi maagilisi tervise ja hea käekäigu tagamise riitusi. Näiteks oli tavaks pesta enne päikesetõusu tervise kindlustamiseks silmi. Silmapesuvette kraabiti veidi hõbedat - tervistamisriituste keskne abivahend - või pesti pajutibude veega.

Lihavõttehommikul pandi kas hõberaha ehk mingisugune muu hõbeasi silmapesuvette ja siis pesti selle veega silmi. Arvati, et siis silmad ikka selgeteks ja terveteks jäävad, kus neid niisuguse veega pestud (E XIII 17 (90) < Nõo khk - Matthias Johann Eisen < Aliide Räss). 
Kiiremale kadumisele on allunud omaaegsed ennustustavad, samuti majandusedu, sh karjakasvatusedu tagav kombestik. Ilmselt on siinjuures enim mõjunud elatusvahendite ja majandusvormide muutumine, mille taustal on hääbunud paljud uskumused ja nendega seotud kombed. Ehkki üksikute tavade järgimine sooviga mitte katkestada põlvkondi järgitud kommet on säästnud mõnes peres mõne vana tava, on see pigem erand kui reegel. Järgnevalt on lühema loeteluga esile toodud kombeid, mida 20. sajandil järgiti ja mis selle vältel kadusid.

Suure neljapäeva hommikul toodi sülega tuppa juhuslikult haaratud katuselaaste või põletispuid - mida rohkem puid tuppa toodi, seda rohkem linnupesi sellel suvel leiti. Sama komme usuti toovat tugevust ja tervist, nii sai ennustada ka abiellumist - paaritu arv puid märkis üksikuks jäämist, paarisarv aga abiellumist. See oli üks ennustusviisidest, mida sooritati lihavõtete kõrval paastumaarjapäeval ja palmipuudepühal, ehkki populaarseim oli see just suurel neljapäeval. Tava nihkus sajandi alguses lastele suunatud ja lastepärimusse ning hääbus juba enne keskkütte tavaliseks saamist, kuid kindlasti selle mõjul, sest linnamajapidamistes ei olnud laaste ega küttepuid, suuremates linnades ka mitte võimalust linnupesi leida.

Üldlevinud olid karjaedu tagavad, loomade tervist ja kasvu kindlustavad, võõraste kurja maagiat kahjutustavad maagilised rituaalid. Nendega taotleti oma karjale piisavat või võimalikult suurt edenemist, mis tähendas selle teistelt omandamist või siis vähemalt kaitset naabrite kadeduse ja nõiduse vastu. Eriliselt kardeti kariloomade ja piima äranõidumist, mille vastuabinõuna lisati loomatoidule ja joogiveele kriitilisel ajal soola, nt asetati laudaläve alla raudese.

Teiste talude piimaõnne nurjamiseks pöörati loomade jälgi ümber, korjati neist puru oma loomade suitsutamiseks; puu otsast või kõrgemalt kohalt käidi varahommikul oma perele piimaõnne hüüdmas või lüpsti imiteerivalt kadakapõõsaid või aiateibaid jne. Näiteks võõrastelt lammastelt sel ajal lõigatud villatopp oli maagiline abivahend kohtulahendi võitmiseks. Needki tulevikku kindlustanud majapidamismaagilised võtted hääbusid uueneva majandamisviisi mõjul kiiresti.

Suur neljapäev oli ka välistööde sümboolne algusmoment (näiteks viidi ja visati põllule kolm hargitäit sõnnikut, künti mõni vagu põldu, põllunurkadesse pandi kaitseks kahetuse ja kurja vastu munakoori, kalavõrk visati korraks vette või parandati seda moe pärast, puhastati püssi). Kriitilisel ajal oli tööriistade liigutamise või nende parandamise ja puhastamise imiteerimise sihiks sobivamal ajal jätkatavatele töödele edenemise ja kaitse tagamine. 


\section{Sümboolsed kingid ja uuemad tähistamisviisid}

20. sajandi jooksul hakkasid paljud kalendripühad muutuma ennekõike olulisteks perepühadeks, mis ühendasid ja tugevdasid hõimusidemeid, külakogukonda, suhteid ristivanemate ja ristilaste, õpetajate ja õpilaste, sõprade ja sugulaste vahel (Vesik 2001: 189). Kui suurem osa talupidamistes järgitud suure neljapäeva ja suure reede kombestikust, eriti aga väikesed maagilised rituaalid kaotasid oma tähenduse elanikkonna linnastudes, ka suurtalud ja hiljem majandid ei vajanud seesuguseid kombeid, siis inimsuhetega seotud ettevõtmised säilitasid oma värvika tähenduse. Tänaselgi päeval on tavaks lihavõttemunade kaunistamine ja vahetamine, nagu ka pajutibude või ajatatud kaseokste tuppatoomine, ja seda mitte üksnes lastega peredes.

Viimasel poolsajandil on lasteaiad, koolid ja lähikümnenditel ka muuseumid institutsioonidena muutunud oluliseks rahvakalendri- ja rahvuslike pühade tugiasutusteks (muuseumidest vt Kõiva 2006: 1598 jj), mis on hoidnud tähtpäeva alles (nt kevadine maarjapäev, jüripäev) või alustanud selle taastähistamist (volbripäev). Näiteks eesti koolides tähistatavate pühade nimestik sisaldab märkimisväärse hulga rahvakalendripühi (vt BERTA 2004). Loomulikult varieerub see nimestik mõnevõrra sõltuvalt piirkonnast: Lääne-Eestis tähistatakse jätkuvalt pühi, mis langevad kokku Skandinaavia vastavate tähtpäevadega (nt luutsi(na)päev, mida nüüd rootslaste eeskujul nimetataksegi luciapäevaks), samal ajal kui Kagu- ja Edela-Eestis tähistatakse vene õigeusu pühi. Sajandeid populaarsete tähtpäevade, nagu mardija kadripäev, kõrval on taaselustatud pühi, nagu hingedepäev, luutsipäev, keskaegseid pühi ja pidustusi, nagu maikrahvi valimine; uustähtpäevi, nagu halloween, valentini- ja volbripäev. Lihavõtete ajal värvitakse lasteaedades ja muuseumides mune, tutvustatakse vanu pühadekombeid, tähtpäevatoite, käsitöövõtteid. Värvitud munadest tehakse näitusi, nendega on koguni ilustatud õues kasvavaid puid. On õpetatud traditsiooniliste munapesade valmistamist, ühiselt lauldud jm. Muuseumid on õpetanud valmistama tühjaks puhutud ja kaunistatud munadega dekoreeritud lihavõttekrooni, mis oli Lääne-Eestis 19. sajandi keskpaiku ja varem populaarne (Õunapuu 2001), taasjuurdunud on see aga üksnes mõnedes peredes. Korraldaja teadmistest, oskustest ja energiast sõltub, kas ja kuidas kombestikku jätkatakse.

Rahvakalendri pühade tähistamist on edendanud ja finantseerinud viimase poolsajandi jooksul ka kohalikud omavalitsused ja kogukonnad (nt vastlad jm). Lihavõtted kuuluvad seesuguste toetatavate pühade hulka taasiseseisvumisest alates. Traditsioonide juurutamisel ja taaselustamisel on olulised olnud noored kultuuritöötajad, kes kultuurielu elavdamiseks tähistavad kalendritähtpäevi (vrd Lukka-Jegikjan 2006). Selles on oluline osa Tallinna Üli- 
kooli kultuurijuhi eriala ja Rahvakultuuri Keskuse täiendkoolituste läbinutel, viimastel kümnenditel eriti aga Viljandi Kultuurikolledži (2005. aastast Tartu Ülikooli Viljandi Kultuuriakadeemia) lõpetanutel - Mikk Sarve ja Ene Lukka-Jegikjani õpilastel. Mõlemad on õpetanud mugandama vanu kombeid moodsasse elukeskkonda.

Vanemate traditsioonide taasedendamisel on märkimisväärne ka maausuliste roll, kelle kodulehe kaudu saab ülevaate paljudest tähtpäevadest (Pühad 2005). Traditsioonide puhul on esile tõstetud fenoloogiline külg ja seosed loodusega, kombekirjeldusi on mugandatud, pühakunimesid püütud vältida, asendades neid omakeelsete, murdeliste või ka keelesugulaste omanimetustega. Kogukond on kujundanud omarituaale ja tähistamisviise.

Lähikümnenditel on muutunud meedia taktika - pikemaid tutvustavaid artikleid ja käsitlusi avaldatakse vähem, ka rahvakalendriteemalised lühirubriigid on taandumas. Uudised pühadest ja pühitsemisest pääsevad ennekõike väiksemate kohalike väljaannete veergudele. Trükimeedia huviorbiidis on pigem uuemad tähtpäevad, mis on kultuuripilti ilmunud hiljaaegu. Seesuguste kirjutiste elavdamiseks on küsitud eksperthinnanguid ajaloolastelt, folkloristidelt, samuti linnakodanikelt (Päärt 2002; Küsitlus 2002). Et ajakirjanduse ülesandeks on uudiste vahendamine, tuuakse teadus- ja rahvakultuuri nähtused lugejaskonna ette sensatsiooni kontekstis, nagu nt Püha Nikolause rekonstrueeritud portree avaldamine pärast tema haua avastamist (Olesk 2004).

\section{Kokkuvõte}

Nõukogude Eesti folkloristikale oli tunnuslik omajuursete põliste eesti tavade reklaamimine teadustöödes ja meedias. Sajandivanused või uuemad kombed tunnistati otsekui ebaautentseks ja tähelepanu mitte väärivateks (lähemalt Kõiva 1996). Sama kehtis rahvusvahelise algupäraga ja tugevate paralleelidega või linnakultuuri juurdunud kommete kohta, kuivõrd folkloor ja eestipärane seostati ennekõike talupojakultuuriga (vt nt Hiiemäe 1981). Et mitmel ajaloolisel põhjusel toimus linnastumine 20. sajandil, on see loomulik hoiak. Laiemalt levinud rahvusromantilisest ideestikust lähtunud käsitlusviisi toetas objektiivne reaalsus - talukultuuriga olid tihedad seosed ja kuigi kiire linnastumine nõudnuks Teise maailmasõja järel vaadete revisjoni, see viibis. Teise maailmasõja järgne talude dekonstrueerimine ja autoritaarne poliitiline diktatuur tekitasid kontrakultuuri, mille rahvusliku identiteedi ja kultuuri alalhoidmise taktikad vajavad eraldi vaatlemist (nõukogudeaegse jõulukombestiku kui perepüha struktuurist on kirjutanud Mall Hiiemäe (2003)). 
Teine eristav joon lahutab põlvkondi, kellest osale tähendavad lihavõtted munadekogumist ja ühiseid pidusid, Teise maailmasõja järgsetele aga ennekõike koduseid pühasid. Tänane lihavõttepüha on ennekõike perekonnapüha, mis ühendab pereliikmeid tervituste, kaartide saatmise, munadevärvimise ja -vahetamise kaudu. Jätkuvalt ja laieneva isikuteringiga vahetatakse mune nii koolis kui ka töökohas, kuid see tava ei ole enam nii üldlevinud. Küll aga on aktuaalne murukasvatamine versus ostmine, okste lehtedesse ajatamine, pajuurbade toomine, kodu kaunistamine lillede ja enamasti laste poolt lõngast valmistatud kanade ja tibupoegadega, ehkki neidki on nüüd laias valikus võimalik poodidest osta.

Niisiis on see pisikinkide, küünalde ja munade aeg, elavate okste või lillede kojutoomise aeg, mis pühade sümbolitena tänini püsivad. Ainsa avaliku kombena säilinud liberaliseerunud munaveeretamine on kujunenud setu identiteedi osaks, mille juures on olulised religioosne ja hõimuidentiteet, mis koos territoriaalse identiteediga eristab setusid muudest eestlastest.

Eesti ühiskonnas 19. sajandi lõpul alanud sekulariseerumisprotsess jätkus jõudsalt järgmisel sajandil. Suuremad muutused majandamisviisis kaotasid pühade kui tööde algus- ja lõputähiste olulisuse, seega ka rituaalselt oluliste perioodide, töökeeldude markeerija rolli, nagu trükitud kalendrite levimine kaotas aja mõotmise rolli. Seni pealiskaudselt käsitletud nõukogude periood oma ülalt alla reguleeritud seadustiku, kultuurielu reglementeerituse ja kirikupühade avaliku tähistamise piiramisega muutis loomuliku arengu suunda sama tugevasti. Poliitiline surve kiirendas sekulariseerumist, põhjustas äkilisi muutusi kombestikus mitte üksnes poliitilistel põhjustel, vaid ka võõrandumise ja kombestiku erosiooni kaudu. Kiire välis- ja sisemigratsiooni tõttu oli lokaalsuse loomine ja traditsioonide alalhoidmine keerukas, kuid teisalt tingis see ka omakultuuri identiteedi selginemise, vastandamise teistsugustele tavadele, nende säilitamise mälus ja tavandis. Eriti kirikupühade, sh lihavõtete rahvapärane tähistamine suruti avalikust sfäärist privaatsesse, institutsioonides tähistati väheseid tähtpäevi: vastlad, naistepäev, maipühad, jaanipäev, mardi- ja kadripäev, näärid.

Siiski ei ole rahvakalendri ja nõukogude aja suhted mustvalged ja üksühesed, kuivõrd ideoloogia nõudis rahvusliku ühendamist rahvusülesega, mis tähendas riiklikku toetust valitud ja ametlikult tunnustatud pühadele. Võimusuhted ja mõjutused nõuavad eraldi uurimust, samuti üksikisikute mõju kalendripühade toetamisele ja kujundamisele: karismaatiliste kiriku- ja kooliõpetajate kõrval on olnud tähtsad kohaliku kultuurielu edendajad. Traditsioonide püsimine on aga alati sõltunud teotahtelistest peredest ja kohalikest noortest - nemad määravad püsimise või hääbumise. 
Viimase kümnendi jooksul on lihavõtted taas tugevalt institutsionaliseerunud. Kiriku osa on nähtavam kui eelmise sajandi vältel ja vähim muutunud. Taasiseseisvumise järel on lihavõtted uuesti riiklik püha, millega kaasnevad temaatilised meediaprogrammid ja ametlik protektsioon. Ehkki kirjutav meedia distantseerub üha enam kalendrikombestiku toetaja ja selgitaja rollist, on seda omal kombel hakanud asendama internet ja lokaalsed veebilehed.

Kombestiku püsimisel ja uuendamisel on erinevate rühmituste kõrval kasvanud kooli ja mäluasutuste, nagu muuseumide ja arhiivide, osa, kes suunavad vanemaid tavasid mäletama ja järgima. Kultuuriosakondade ja kaubandusettevõtete munalaadad ja -näitused, temaatilised etendused jmt muudavad tähistamise mitmekesiseks, andes sellele uusi innovatiivseid jooni. Just 20. sajandi muutlikud majandus- ja poliitilised olud osutavad, et piiratud võimaluste juures pöördutakse tagasi varasemate oskuste juurde ja leitakse moodused, kuidas tarvilikku ise valmistada, kompenseerides nii kauba- ja võimaluste puudust.

Kaubakülluse ja kommertsialiseerumise olukorras on lihavõtetele tunnuslikku võimalik poest osta. Vaieldamatult muudab see pühitsemise mugavaks ja vähendab oma initsiatiivi, kuid ei vähenda pühade peamist sõnumit ega lähedasi ühendavat tähendust.

\section{Arhiiviallikad}

Eesti Rahvaluule Arhiivi käsikirjad:

$\mathrm{E}=$ Matthias Johann Eiseni käsikirjaline rahvaluulekogu aastaist 1880-1934.

RKM = Eesti Kirjandusmuuseumi rahvaluule osakonna käsikirjaline rahvaluulekogu aastaist 1945-1995.

\section{Kirjandus}

Appadurai, Arjun 1986. Commodities and the Politics of value. Appadurai, Arjun (toim). The Social Life of Things: Commodities in Cultural Perspectives. Cambridge \& New York: Cambridge University Press, lk 3-63.

Bell, Catherine M. 1992. Ritual Theory, Ritual Practice. New York: Oxford University Press.

Bell, Catherine M. 1997. Ritual: Perspectives and Dimensions. New York: Oxford University Press.

BERTA 2004 = Kõiva, Mare \& Särg, Taive \& Vesik, Liisa (koost). BERTA: Eesti Rahvakalendri tähtpäevade andmebaas. Tartu: Eesti Kirjandusmuuseumi rahvausundi ja meedia töörühm (http://www.folklore.ee/Berta - 14. aprill 2006). 
Eike, Christine 2002. Disguise as Ritualised Humour in Norway: Past and Present. Traditional Masks and Mumming in Northern Europe: An Interdiciplinary Conference in Turku, Finland 16.-18. August 2002: Papers from the Conference. Turku. Manuscript. (http://www.hi.is/ terry/turku/Turku_CHRISTINE_EIKE.htm - 14. aprill 2006).

Hiiemäe, Mall (koost) 1981. Eesti rahvakalender 2: Rahvapärimusi alates kevadisest pööripäevast ja lõpetades lihavõttepühadega. Tallinn: Eesti Raamat.

Hiiemäe, Mall 2003. Nõukogudeaegsed jõulud. Krikmann, Arvo \& Olesk, Sirje (toim). Võim \& kultuur. Tartu: Eesti Kirjandusmuuseum \& Eesti Kultuuriloo ja Folkloristika Keskus, lk 339-383.

Kena, Ranno 2006. Minu pere traditsioonid. Miksike (http://www.miksike.ee/docs/referaadid/minu_pere_traditsioonid_ranno.htm - 14. juuni 2006).

Kõiva 1990 = Кыйва, Маре. Эстонские загоборы: Структура и жанробые особенности. Väitekiri. Tallinn: Eesti Akadeemiline Raamatukogu. Käsikiri.

Kõiva, Mare 1996. Traditsioonist taas. Murutar, Asser (koost). Maarahva elujõud müüdid ja tegelikkus. Tartu: Elmatar, lk 25-32.

Kõiva, Mare 2006. Kas ikka veel tolmunud ruum? Muutustest muuseumikultuuris. Akadeemia 7, lk 1588-1607.

Küsitlus $2002=$ [Päärt, Villu]. Kas halloween on võtmas kohta eesti rahvakalendris? Postimees, 31. oktoober (http://vana.www.postimees.ee/index.html?op=lugu\&id=77419 -24. märts 2006).

Lukka-Jegikjan, Ene 2006. Tähtpäevade ja pühade tähistamisest Viljandi Kultuuriakadeemias. Mäetagused: Hüperajakiri 32, lk 151-164 (http://www.folklore.ee/tagused/nr32/lukka.pdf).

Lyle, Emily 1998. Scottish customs in a wider context: The Henry Duncan Prize Lecture delivered to the Royal Society of Edinburgh on $10^{\text {th }}$ November 1997. Occasional papers series 1. Edinburgh: University of Edinburgh, School of Scottish Studies.

McCauley, Robert N. \& Lawson, E. Thomas 2002. Bringing Ritual to Mind: Psychological Foundations of Cultural Forms. Cambrigde \& New York: Cambridge University Press.

Mänd, Anu 2004. Pidustused keskaegse Liivimaa linnades 1350-1550. Tallinn: Eesti Keele Sihtasutus.

Olesk, Arko 2004. Briti teadlased taastasid esimese jõuluvana näo. Postimees, 24. detsember (http://www.postimees.ee/241204/esileht/valisuudised/153499.php - 14. aprill 2006).

Plaat, Jaanus 2001. Usuliikumised, kirikud ja vabakogudused Lääne- ja Hiiumaal: Usuühenduste muutumisprotsessid 18. sajandi keskpaigast kuni 20. sajandi lõpuni. Eesti Rahva Muuseumi sari 2. Tartu: Eesti Rahva Muuseum.

Päärt, Villu 2002. Kõrvitsalõikumispüha toob lastele kuhjaga kommi. Postimees, 31. oktoober (http://vana.www.postimees.ee/index.html?op=lugu\&rubriik=49\&id=77440\& number $=645-14$. aprill 2006).

Pühad 2005. Maavalla Koda (http://www.maavald.ee/maausk.html?op=rubriik\& rubriik=61 -14 . aprill 2006). 
Russow, Balthasar 1993. Liivimaa kroonika. Tallinn: Hotger.

Sild, Olav 1938. Eesti kirikulugu: Vanimast ajast olevikuni. Tartu: Akadeemiline Kooperatiiv.

Simpson, Jacqueline \& Roud, Steve 2000. A Dictionary of English Folklore: Traditional beliefs, customs, myths, and superstitions. Oxford paperback reference. Oxford \& New York: Oxford University Press.

Sõtšov, Andrei 2004. Eesti õigeusu piiskopkond Stalini ajal aastail 1945-1953. Tartu: Tartu Ülikooli Kirjastus.

Sökefeld, Martin 1999. Debating Self, Identity, and Culture in Anthropology. Current Anthropology 40: 4, lk 417-447.

Šmits, Pēteris 1940-1941. Latviešu tautas ticējumi 1-4. Latviešu folkloras krātuves materiāli. Rīga: Latviešu folkloras krātuve.

Talve, Ilmar 1961. Keinu ja keinuminen Suomessa. Scripta Ethnologica 11. Turku: Turun Yliopiston Kansantieteen Laitoksen Julkaisuja.

Tensmann, Eduard 2005 [1931]. Ajalooline traditsioon Jõhvi kihelkonnas 1931. a. suvel. Tartu: Eesti Kirjandusmuuseumi rahvausundi ja meedia töörühm (http://www. folklore.ee/radar/digi_pre.php?area=J\%F5hvi - 14. aprill 2006).

Vesik, Liisa 2000. Tähtpäevad tänapäeva Kagu-Eestis. Koreinik, Kadri \& Rahman, Jan (toim). A kiilt rahvas kynõlõs...: Võrukeste keelest, kommetest, identiteedist. Võro Instituudi Toimõtiseq 8. Võru: Võro Instituut, lk 87-104; 181-206.

Viires, Ants 2002. Meie jõulude lugu. Tallinn: Eesti Entsüklopeediakirjastus.

Vissel, Anu 2003. Eestlaste kiigekultuur enne ja nüüd. Mäetagused: Hüperajakiri 21, lk 7-81 (http://www.folklore.ee/tagused/nr21/kiik.pdf - 14. aprill 2006).

Westrén-Doll, August Oswald 1926. “Abgötterey” zu Ausgang der schwedischen und Beginn der russischen Zeit. Opetatud Eesti Seltsi Aastaraamat = Sitzungsberichte der Gelehrten Estnischen Gesellschaft 1925. Tartu, lk 7-25.

Õunapuu, Piret 2001. Pühad ja kombed. Tallinn: Tänapäev.

\section{Summary}

\section{Easter in Estonia in the $20^{\text {th }}$ Century}

Mare Kõiva

Key words: Southeast Estonia, Easter, Easter eggs, folk calendar, tradition

This article aims to present an overview of changes in the Easter tradition in Estonia throughout centuries and to characterise its celebration in modern times. Also, a brief introduction of the local peculiarities of the tradition in a nation state, the role of an individual in continuing the tradition, as well as the impact of politics and the idea of ethnicity on calendar tradition will be presented. For the present article extensive 
use of one of our most recent Web-based databases/portals, which is intended to inform users about the ritual Estonian folk calendar, has been made. The sources to study the earlier calendar tradition are relatively scanty; moreover, the material has been primarily collected from the town population, especially members of the upper and middle class, which explains why the collectors recorded mostly the tradition of nonEstonians and integrated immigrants. The most popular Easter custom in the European countries and also in Estonia was decorating and eating Easter eggs and giving these as gifts: this is the main private symbol of the date in popular culture. In the Orthodox regions of South Estonia it was also customary to roll the eggs. An important part of the $20^{\text {th }}$ century Easter tradition was self-made or printed Easter postcards sent to friends and family. In Estonia, the postcards usually depicted chickens with painted eggs, Easter bunnies with eggs, willow catkins, etc. Already in the $19^{\text {th }}$ century, the masking and mumming tradition was particularly rich in west Estonia and on the islands, and shared similarities with the corresponding customs in Scandinavia or customs of wider spread. Easter masking and mumming, formerly more widely known, was later observed in the same area, probably because of analogous celebration of other holidays. A characteristic feature of the tradition in western Estonia and on the islands was "mummers" in animal or bird costumes who visited people to wish good luck or health. In the Estonian Easter tradition, decorated Easter eggs played an important role in the communication between relatives, godparents and godchildren, and villagers. Next to expressing liking, respect and family ties, Easter eggs were also used to demonstrate dislike and ridicule. While cracking eggs was a very popular and widespread custom, egg-rolling was mostly known in South-East Estonia, which the whole village gathered to look on. As the period coincided with the beginning of the swinging period, people used to swing, sing, eat home-baked pastry and chat. Over the centuries there have been many outdoor activities and celebrations during Eastertide. An Easter custom practised in northern and central Estonia was board-jumping, which was skilfully mastered by youngsters and children. During the Holy Week and the Easter Sunday smaller rituals of magic were performed to secure good luck and health for the performer. Magic of the period focussed on cattle, aiming to procure them health and growth, and also to protect them against evil external magic. Maundy Thursday marked the symbolic beginning of outdoor work. Good Friday was also good for love magic, to make someone love you or break up someone else's relationship. In the $20^{\text {th }}$ century many folk feast days turned into important family holidays, which united and strengthened family ties, village communities, relationships between godparents and godchildren, teachers and pupils, friends and relatives. The bulk of Maundy Thursday and Good Friday rituals have disappeared. Easter traditions, on the other hand, have changed over the past few centuries but have retained their manifold relevance. During the past decades, kindergartens, schools and museums have become increasingly important in celebrating Easter and other national and calendar holidays. For example, the list of holidays celebrated in Estonian schools includes a remarkable number of former folk calendar holidays. Official institutions have helped to support and promote the celebration of Easter, which is primarily a holiday of domestic culture; such institutional celebration has helped to preserve many folk calendar holidays and has revived the celebration of others. 